\title{
Impacts of 21st century climate change on global air pollution-related premature mortality
}

\author{
Yuanyuan Fang • Denise L. Mauzerall • Junfeng Liu • \\ Arlene M. Fiore • Larry W. Horowitz
}

Received: 29 May 2012 / Accepted: 16 July 2013 /Published online: 27 August 2013

C) The Author(s) 2013. This article is published with open access at Springerlink.com

\begin{abstract}
Climate change modulates surface concentrations of fine particulate matter $\left(\mathrm{PM}_{2.5}\right)$ and ozone $\left(\mathrm{O}_{3}\right)$, indirectly affecting premature mortality attributed to air pollution. We estimate the change in global premature mortality and years of life lost (YLL) associated with changes in surface $\mathrm{O}_{3}$ and $\mathrm{PM}_{2.5}$ over the 21 st century as a result of climate change. We use a global coupled chemistry-climate model to simulate current and future climate and the effect of changing climate on air quality. Epidemiological concentration-response relationships are applied to estimate resulting changes in premature mortality and YLL. The effect of climate change on air quality is isolated by holding emissions of air pollutants constant while allowing climate to evolve over the 21 st century according to a moderate projection of greenhouse gas emissions (A1B scenario). Resulting changes in 21 st century climate alone
\end{abstract}

Electronic supplementary material The online version of this article (doi:10.1007/s10584-013-0847-8) contains supplementary material, which is available to authorized users.

Y. Fang • D. L. Mauzerall $(\bowtie)$

Woodrow Wilson School of Public and International Affairs, Princeton University, Princeton, NJ 08544, USA

e-mail: mauzeral@princeton.edu

Y. Fang

Department of Global Ecology, Carnegie Institution for Science, Stanford, CA 94305, USA

D. L. Mauzerall

Civil and Environmental Engineering Department, Princeton University, Princeton, NJ08544, USA

J. Liu

College of Urban and Environmental Sciences, Peking University, Beijing, China 100871

A. M. Fiore

Department of Earth and Environmental Sciences, Columbia University and Lamont Doherty Earth Observatory, Palisades, NY, USA

L. W. Horowitz

Geophysical Fluid Dynamics Laboratory, National Oceanic and Atmospheric Administration, Princeton, NJ 08540, USA 
lead to an increase in simulated $\mathrm{PM}_{2.5}$ concentrations globally, and to higher (lower) $\mathrm{O}_{3}$ concentrations over populated (remote) regions. Global annual premature mortality associated with chronic exposure to $\mathrm{PM}_{2.5}$ increases by approximately 100 thousand deaths $(95 \%$ confidence interval, CI, of 66-130 thousand) with corresponding YLL increasing by nearly 900 thousand ( $95 \%$ CI, 576-1,128 thousand) years. The annual premature mortality due to respiratory disease associated with chronic $\mathrm{O}_{3}$ exposure increases by $+6,300$ deaths $(95 \%$ CI, 1,600-10,400). This climate penalty indicates that stronger emission controls will be needed in the future to meet current air quality standards and to avoid higher health risks associated with climate change induced worsening of air quality over populated regions.

$\begin{array}{ll}\text { Abbreviations } \\ \mathrm{O}_{3} & \text { Ozone } \\ \mathrm{PM}_{2.5} & \text { Fine particulate matter with an aerodynamic diameter less than } 2.5 \mu \mathrm{m} \\ \text { YLL } & \text { Years of life lost } \\ \text { GFDL } & \text { Geophysical Fluid Dynamics Laboratory } \\ \text { AM3 } & \text { Atmospheric model version 3 } \\ \text { CI } & \text { Confidence interval } \\ \text { CCM } & \text { Coupled chemistry-climate model } \\ \text { CTM } & \text { Chemical transport model } \\ \text { GCM } & \text { General circulation model } \\ \text { LCT } & \text { Low concentration threshold } \\ \text { GHG } & \text { Greenhouse gas }\end{array}$

\section{Introduction}

Climate change is projected to harm human health through adverse changes in food production, heat stress, sea level rise, increased storm intensity, flooding and droughts, increased incidence of vector-borne diseases, etc. (Portier et al. 2010; Tanser et al. 2003; Hales et al. 2002; Rosenzweig et al. 2001; Parry et al. 2007). In addition, climate change also affects surface concentrations of air pollutants, such as fine particulate matter $\left(\mathrm{PM}_{2.5}\right.$, particulate matter $\leq 2.5 \mu \mathrm{m}$ in aerodynamic diameter) and ozone $\left(\mathrm{O}_{3}\right)$, which are associated with increases in human morbidity and premature mortality (WHO 2008a).

A number of global chemical-transport models (CTM) driven by off-line general circulation model (GCM) future-climate fields have investigated the effect of 21 st century climate change on surface $\mathrm{O}_{3}$ and $\mathrm{PM}_{2.5}$. They have allowed climate to change while maintaining constant emissions of air pollutants over the 21 st century. These studies consistently predict an increase in $\mathrm{O}_{3}$ concentrations $(+1-10 \mathrm{ppbv}$ annually or during summers) over highly polluted northern mid-latitude regions (Jacob and Winner 2009; Weaver et al. 2009; Murazaki and Hess 2006; Liao et al. 2006; Fiore et al. 2012) and changes in global $\mathrm{PM}_{2.5}$ ( $\pm 0.1-1 \mu \mathrm{g} \mathrm{m}^{-3}$ annually or during summer) due to projected $21 \mathrm{st}$ century climate change (Jacob and Winner 2009; Fiore et al. 2012). Recent sensitivity studies using newly coupled chemistry-climate models (CCM) provide a more integrated way to examine climate change impacts on surface air quality, as they allow coupling and feedbacks between dynamics, chemistry and physics, all of which directly affect air pollutant levels. CCM studies suggest that $\mathrm{PM}_{2.5}$ and aerosol concentrations may increase in a warmer climate because stratiform precipitation (a dominant driver for wet scavenging in the model) decreases when and where soluble pollutants are most abundant (Kloster et al. 2010; Fang et al. 2011). 
Elevated concentrations of $\mathrm{PM}_{2.5}$ and $\mathrm{O}_{3}$ are detrimental to public health. Exposure to $\mathrm{PM}_{2.5}$ is associated with an increased relative risk of lung cancer, cardiopulmonary and allcause mortalities (Pope et al. 2002; Pope and Dockery 2006) while $\mathrm{O}_{3}$ exposure is associated with increased incidence of cardiovascular, respiratory and all-cause mortality (Jerrett et al. 2009; Levy et al. 2005; Bell et al. 2004). As climate change leads to changes in surface $\mathrm{O}_{3}$ and $\mathrm{PM}_{2.5}$, it indirectly affects human health risks associated with these pollutants. Only a few studies have investigated the potential impact of climate change on air-quality relevant health in the United States: Bell et al. (2007) project that total daily mortalities in 50 U.S. cities will increase by $0.11-0.27 \%$ from 2000 s to 2050 s due to increases in surface $\mathrm{O}_{3}$ concentrations resulting from climate change; Tagaris et al. (2009) projects that, due to climate driven changes in $\mathrm{PM}_{2.5}$ and $\mathrm{O}_{3}$, annual U.S. mortalities will increase by 4,300 deaths from 2001 to 2050 . Here we go beyond previous work to use one of the first fully coupled global CCM to examine the effect of climate change induced changes in $\mathrm{PM}_{2.5}$ and $\mathrm{O}_{3}$ air quality over the 21 st century on premature mortalities globally.

\section{Methods}

We use the Geophysical Fluid Dynamics Laboratory (GFDL) Atmospheric Model version 3 (AM3) global coupled CCM (Donner et al. 2011) to simulate present and future climate and air quality. AM3 builds on the capabilities of AM2 (Atmospheric Model, version 2) (GAMDT 2004), a climate model ranked among the best in the Intergovernmental Panel on Climate Change Fourth Assessment Report (IPCC AR4) (Reichler and Kim 2008) by adding tropospheric gas chemistry from the 3-D global CTM MOZART-2 (Horowitz et al. 2003), aerosol chemistry from the GOCART model (Ginoux et al. 2001), and interactions between clouds and aerosols (Ming et al. 2006).

Using AM3, we design a pair of sensitivity experiments ("present" and "future") for this study. The "present" simulation is driven by a 1981-2000 climatology of observed monthly mean sea surface temperatures and sea ice. The "future" simulation is driven by this observed climatology plus the 19-model (from IPCC AR4) ensemble mean difference of 20-year average values from 1981-2000 to 2081-2100 under the moderate SRES A1B scenario. The concentrations of the long-lived greenhouse gases $\left(\mathrm{CO}_{2}, \mathrm{~N}_{2} \mathrm{O}\right.$ and CFCs $)$ are set to 1990 values for the present but 2090 (A1B) values for the future simulation. $\mathrm{CH}_{4}$ is set to the 1990 level for tropospheric chemistry calculations in both simulations, but for radiation it is set to the 1990 and A1B 2090 levels in the current-day and future simulations, respectively. Emissions of short-lived pollutants in both present and future simulations are set to present levels, repeated annually. Each simulation is run for 20 years following a 1year spin-up. Detailed configuration information can be found in Table S1 in the SI and in Fang et al. (2011, 2013a). With these configurations, changes in the surface concentrations of $\mathrm{PM}_{2.5}$ and $\mathrm{O}_{3}$ result entirely from changes in climate. Sensitivity experiments have been widely used in atmospheric chemistry and climate communities to isolate the impact of future climate on air quality (ACCMIP 2012; Fiore et al. 2012; Jacob and Winner 2009). Under the A1B scenario, the simulated global surface temperature and precipitation increase by $2.7{ }^{\circ} \mathrm{C}$ and $6 \%$ respectively, consistent with the IPCC AR4 model ensemble mean (Meehl et al. 2007). We further evaluate simulated present surface $\mathrm{O}_{3}$ and $\mathrm{PM}_{2.5}$ (including sulfate, nitrate, fine dust particles, secondary organic aerosols, fine sea salt, black carbon and organic matter) with available observations and find that AM3 generally captures their magnitude and spatial distributions (see Figures S1-S3 in the SI). 
The premature mortalities associated with simulated changes in surface $\mathrm{O}_{3}$ and $\mathrm{PM}_{2.5}$ due to the changing climate is calculated using concentration-response relationships that relate changes in pollutant concentrations to changes in mortality. Health impact functions for both $\mathrm{O}_{3}$ and $\mathrm{PM}_{2.5}$ are based on a log-linear relationship between relative risk and concentration. The excess mortalities attributable to air pollution $(\Delta M o r t)$ are described by:

$$
\Delta \text { Mort }=P O P \times \text { Mort }_{\text {base }} \times\left(1-e^{-\beta \times \Delta X}\right),
$$

where $\beta$ is the concentration-response factor (the estimated slope of the log-linear relationship between concentration and mortality), $\Delta \mathrm{X}$ is the change in pollutant concentration due to climate change, Mort $_{\text {base }}$ is the baseline mortality rate and $P O P$ is the size of the exposed population.

For $\mathrm{PM}_{2.5}$, we use $\beta$ from Krewski et al. (2009), which indicates a $6 \%$ (95 \% CI, 4-8 \%) increase in relative risk of all-cause mortality per $10 \mu \mathrm{g} / \mathrm{m}^{3}$ enhancement in annual mean $\mathrm{PM}_{2.5}$ for Americans age 30 and above from a reanalysis of the American Cancer Society epidemiological study (Pope et al. 2002). To minimize internal model variability, climate change impacts on air quality $(\Delta X)$ are represented as the difference between the 20 -year average of $\mathrm{PM}_{2.5}$ concentrations in the "future" and "present" simulations.

For surface $\mathrm{O}_{3}$, we use $\beta$ from Jerrett et al. (2009), another reanalysis of the ACS cohort study. They find a $4 \%(95 \% \mathrm{CI}, 1.3-6.7 \%)$ increase in relative risk of death from respiratory disease due to a $10 \mathrm{ppbv}$ increase in average daily maximum $\mathrm{O}_{3}$ during the 6 months of highest U.S. $\mathrm{O}_{3}$ (Apr 1st-Sept 30th). Months during which maximum $\mathrm{O}_{3}$ concentrations occur vary depending on location. To be consistent with Jerrett et al. (2009), for each grid, we use the average of the 6 months with highest monthly average daily 1-h maximum $\mathrm{O}_{3}$ (health-relevant $\mathrm{O}_{3}$, denoted as $\mathrm{H}-\mathrm{O}_{3}$ hereafter) within a year as the indicator of $\mathrm{O}_{3}$ exposure. This permits us to include maximum $\mathrm{O}_{3}$ concentrations in regions (e. g. East and South Asia) that have lower $\mathrm{O}_{3}$ concentrations in summer than in spring and fall ( $\mathrm{Li}$ et al. 2007; Mauzerall et al. 2000). $\Delta \mathrm{X}$ of $\mathrm{O}_{3}$ is then represented as the difference between the 20-year average $\mathrm{H}-\mathrm{O}_{3}$ concentrations in the "future" and "present" simulations. When 6 consecutive months with highest maximum $\mathrm{O}_{3}$ within a year are used (Anenberg et al. 2010), similar results are obtained.

The exposed population $(P O P)$ is calculated by multiplying the year 2000 global population in each model grid (CIESIN 2005) by the percentage of adults age 30 and older (WHO 2004) in each grid. The baseline all-cause mortality rates (Mort base $_{\text {e }}$ for adults age 30 and older is from (WHO 2004).

Years of life lost (YLL) estimates the number of years of life lost for each premature death relative to life expectancy and it varies among different populations depending on their age structure and health profiles. For its 14 sub-regions, WHO (2008b) provides YLL (calculated by using a discount rate and a non-uniform age weighting, which we define here as $\mathrm{YLL}_{\text {base}}$ ) and mortality rate (defined here as $\mathrm{Mort}_{\text {base }}$ ) for various disease categories. We calculate years of life lost (YLL) associated with premature mortalities using the baseline YLL per death $\left(Y L L_{\text {per death }}\right)$ :

$$
Y L L_{\text {per death }}=\frac{Y L L_{\text {base }}}{\text { Mort }_{\text {base }}} .
$$

Changes in YLL resulting from climate change induced changes in air pollution can therefore be calculated as:

$$
\triangle Y L L=\Delta \text { Mort } \times Y L L_{\text {per death }}
$$


In this paper, we isolate the effects of climate change on air pollution induced premature mortality by maintaining identical population, age distribution and baseline mortality in our "present" and "future" calculations. This approach has been used in previous studies to isolate the effect of climate change on health (Bell et al. 2007; Tagaris et al. 2009). We choose 10 regions (Figure S4 in the SI) to calculate the regional mean mortality and YLL responses to the impact of climate change on air pollution exposure. The size of the population age 30 and over and their corresponding baseline mortality rate from all-cause and respiratory disease over each region are shown as Table S2 in the SI. We use GIS software to map population and mortality data onto the model grid, and then apply equations (H1) and (H3) in each grid cell and sum globally to estimate the global change in premature mortality and YLL.

Epidemiological literature provides little evidence for any concentration threshold for either $\mathrm{O}_{3}$ or $\mathrm{PM}_{2.5}$ (Jerrett et al. 2009; Krewski et al. 2009; Schwartz et al. 2007; Pope and Dockery 2006). However, there is limited health data available at very low pollutant concentrations and mortality relationships below measured concentrations can only be estimated (i.e., Bell et al. 2006). To account for this uncertainty, previous studies choose to include a low concentration threshold (LCT) to account for natural background concentrations of $\mathrm{O}_{3}$ and $\mathrm{PM}_{2.5}$ (Anenberg et al. 2010, 2009; West et al. 2006a). Following previous literature, we conducted our estimates both with and without a LCT. By including a LCT, we assume $\mathrm{O}_{3}$ and $\mathrm{PM}_{2.5}$ have no effect on mortality below the LCT; by not including LCT, we assume the epidemiological function is valid even when $\mathrm{O}_{3}$ and $\mathrm{PM}_{2.5}$ concentrations are low. We find the application of a LCT of $25 \mathrm{ppbv} \mathrm{O}_{3}$ and $5.8 \mu \mathrm{g} / \mathrm{m}^{3} \mathrm{PM}_{2.5}$ (Anenberg et al. 2010; West et al. 2006a) changes our results very little.

\section{Results}

3.1 Impact of 21 st century climate change on surface air quality

1) Changes in surface $P M_{2.5}$

Simulated changes in surface $\mathrm{PM}_{2.5}$, resulting from 21st century climate change are shown in Fig. 1. $\mathrm{PM}_{2.5}$ increases over most regions, with a global mean increase of $0.28 \mu \mathrm{g} / \mathrm{m}^{3}\left(0.48 \mu \mathrm{g} / \mathrm{m}^{3}\right.$ when weighted by population, greater than the global average,

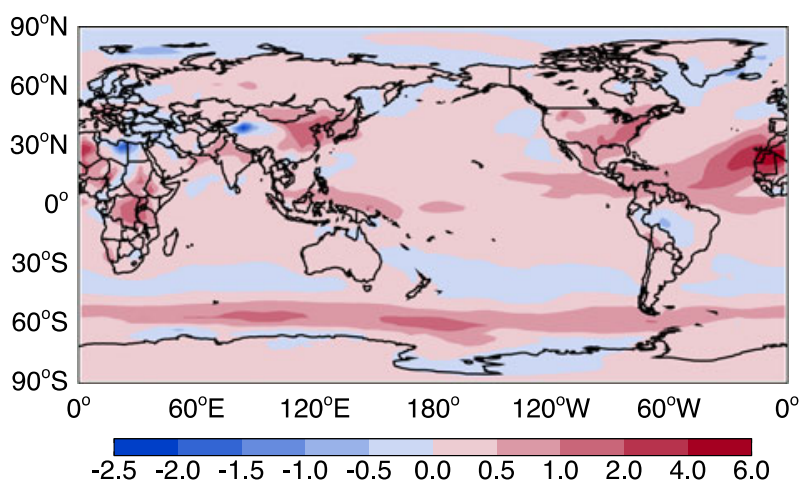

Fig. 1 Climate change induced changes in annual mean surface $\mathrm{PM}_{2.5}$ concentrations from late 20th century (1981-2000) to late 21st century (2081-2100) (unit: $\mu \mathrm{g} / \mathrm{m}^{3}$ ). See supplementary material for changes in components of $\mathrm{PM}_{2.5}$ 
indicating a greater increase over more populated areas). Among all $\mathrm{PM}_{2.5}$ components, the largest increases are in sulfate, smaller dust particles and organic matter. Changes in major $\mathrm{PM}_{2.5}$ components are shown as Figure S5 in the SI. This increase in $\mathrm{PM}_{2.5}$ is mainly because stratiform precipitation, which dominates wet deposition in AM3, decreases in the locations where and seasons when soluble pollutants are most abundant, leading to less wet deposition (Fang et al. 2011). The dominance of stratiform precipitation has been confirmed by a more physically-based diagnostic cloud nucleation model (Croft et al. 2010). In addition, increased sulfate concentrations also result from an increase in hydrogen peroxide $\left(\mathrm{H}_{2} \mathrm{O}_{2},+12 \%\right.$ globally due to higher moisture and $\mathrm{OH}$ concentrations) that leads to increase in-cloud production of sulfate $\left(\mathrm{SO}_{2}+\mathrm{H}_{2} \mathrm{O}_{2}->\mathrm{H}_{2} \mathrm{SO}_{4}\right)$ (Liao et al. 2006; Racherla and Adams 2006).

As shown in Fig. 1, in the northern hemisphere, surface $\mathrm{PM}_{2.5}$ increases substantially near source regions (e.g., over East Asia, eastern United States, northern India, and Africa). These source regions are usually highly populated and hence, increases in $\mathrm{PM}_{2.5}$ will adversely impact human health. With climate change, surface $\mathrm{PM}_{2.5}$ concentrations decrease over western Brazil, parts of northern Europe, the Middle East and parts of North Africa, suggesting a potential "climate benefit" for air quality there.

2) Changes in surface $\mathrm{O}_{3}$

Surface $\mathrm{O}_{3}$ concentrations respond differently than $\mathrm{PM}_{2.5}$ to projected 21 st century climate change (Fig. 2a). The global annual mean $\mathrm{O}_{3}$ concentration changes by $-1.3 \mathrm{ppbv}$ ( -0.2 ppbv when weighted by population) with largest reductions occurring over remote oceanic regions and increases occurring over many polluted continental regions. The decrease in $\mathrm{O}_{3}$ concentrations over remote oceanic regions and in the global mean is largely driven by an increase in water vapor in the warmer future atmosphere (Fig. 2b), which leads to increases in $\mathrm{HO}_{\mathrm{x}}\left(\mathrm{HO}_{\mathrm{x}}=\mathrm{OH}+\mathrm{HO}_{2}\right)$ concentrations. Reaction with $\mathrm{HO}_{\mathrm{x}}$ is the primary sink of $\mathrm{O}_{3}$ at low $\mathrm{NO}_{\mathrm{x}}\left(\mathrm{NO}_{\mathrm{x}}=\mathrm{NO}+\mathrm{NO}_{2}\right)$ concentrations. However, over regions with large $\mathrm{NO}_{\mathrm{x}}$ emissions such as south China, north India, northeast United States and central Africa, we project surface $\mathrm{O}_{3}$ will increase (Liao et al. 2006; Murazaki and Hess 2006). Factors contributing to this increase include: 1) more abundant $\mathrm{HO}_{\mathrm{x}}$ due to increased water vapor converting more $\mathrm{NO}$ to $\mathrm{NO}_{2}$ and hence enhancing $\mathrm{O}_{3}$ production when $\mathrm{NO}_{\mathrm{x}}$ concentrations are high; and 2) higher temperatures decreasing the net formation of peroxyacetyl nitrate $\left(\mathrm{PAN}, \mathrm{CH}_{3} \mathrm{C}(\mathrm{O}) \mathrm{OONO}_{2}\right)$, a reservoir species for $\mathrm{NO}_{\mathrm{x}}$ ), and hence, more $\mathrm{NO}_{\mathrm{x}}$ remaining near its source regions (Fig. 2c), which in turn may enhance local $\mathrm{O}_{3}$ production. Both higher water vapor concentrations and temperature contribute to higher surface $\mathrm{O}_{3}$ concentrations where $\mathrm{NO}_{x}$ is abundant and lower concentrations where it is scarce, partially explaining the tendency of surface $\mathrm{O}_{3}$ to increase over polluted continental regions and decrease over remote oceanic regions. Consistent with earlier studies (Mickley et al. 2004; $\mathrm{Wu}$ et al. 2008), we also find weaker cyclones and more stagnation over the northeastern United States under future climate (the root mean square of 2-8 day band-pass filtered $500 \mathrm{hPa}$ geopotential height, as a measure of the climatological cyclone track, decreases by $2-10 \%$ ), which likely also contributes to increased surface $\mathrm{O}_{3}$ over the northeastern US.

Projected changes in $\mathrm{H}-\mathrm{O}_{3}$ have a similar pattern as the changes in annual mean $\mathrm{O}_{3}$ shown in Fig. 2a. However, $\mathrm{H}-\mathrm{O}_{3}$ generally has a larger increase over highly polluted regions because daily maximum concentrations over these regions are more driven by local daytime photochemical production. As a result, the populationweighted $\mathrm{H}-\mathrm{O}_{3}$ actually increases by $0.3 \mathrm{ppbv}$, suggesting an overlap of increase in $\mathrm{H}-\mathrm{O}_{3}$ and dense population. 


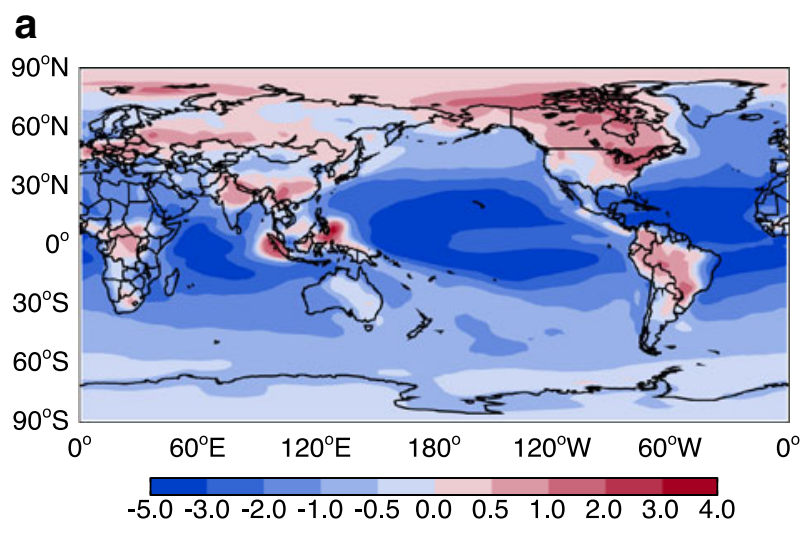

b

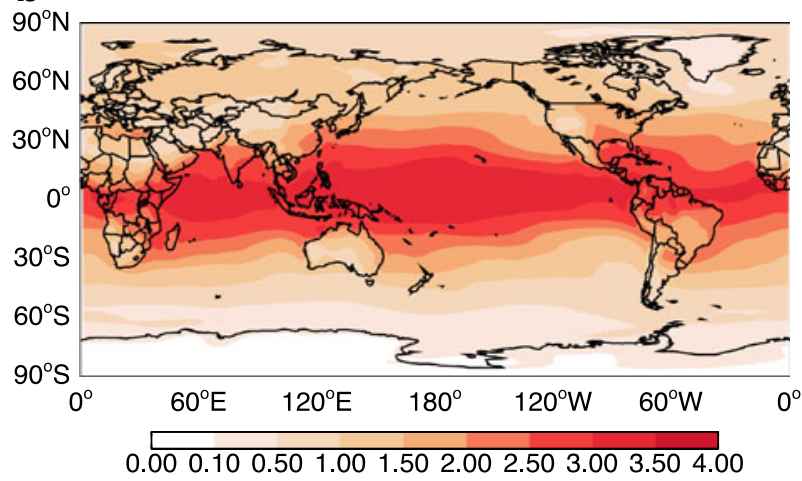

C

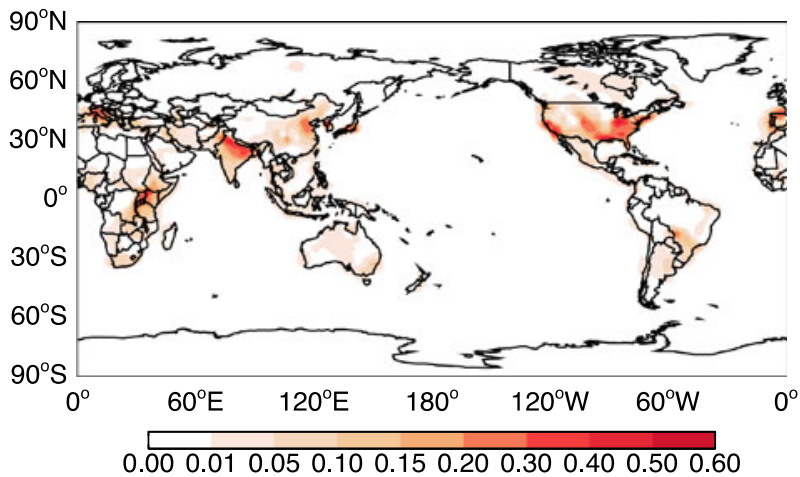

Fig. 2 Late 20th century ("present") to late 21st century ("future") climate change induced changes in annual mean surface a $\mathrm{O}_{3}$ concentrations (ppbv), b specific humidity ( $\mathrm{g} / \mathrm{kg}$ ), and $\mathbf{c} \mathrm{NO}_{\mathrm{x}}$ concentrations (ppbv)

3.2 Climate change induced air quality impact on premature mortality

1) Effects of $P M_{2.5}$

Applying the simulated climate change induced changes in $\mathrm{PM}_{2.5}$ concentrations in (H1), we find that global premature mortalities associated with $\mathrm{PM}_{2.5}$ increase by approximately 100,000 deaths (95\% CI: 66,000-130,000) without a LCT and 93,000 
deaths $(95 \% \mathrm{CI}, 63,000-123,000)$ with a LCT of $5.8 \mu \mathrm{g} / \mathrm{m}^{3}$ (Fig. 3). We additionally present percentage changes in mortalities (defined as the ratio between changes in mortality associated with $\mathrm{PM}_{2.5}$ divided by present-day mortalities associated with $\mathrm{PM}_{2.5}$ ). The present mortality associated with $\mathrm{PM}_{2.5}$ is estimated by using the present-day total $\mathrm{PM}_{2.5}$ concentration in (H1). We continue using the LCT for calculating present mortalities. Regardless whether the LCT is included or not, we find about a $4 \%$ (difference less than $0.1 \%$ ) increase in global premature mortalities due to changes in $\mathrm{PM}_{2.5}$ resulting from $21 \mathrm{st}$ century climate change. As the difference is small, we only report the relative change without LCT hereafter. As summarized in Table S3 in the SI, the increase in mortality associated with $\mathrm{PM}_{2.5}$ exposure is strongest in East and South Asia where population density is highest; the relative increase, however, is largest over North America ( $+8 \%)$, consistent with its greater relative change in $\mathrm{PM}_{2.5}$ concentrations under future climate.

2) Effects of Ozone

The simulated change in $\mathrm{O}_{3}$ concentrations due to 21 st century climate change leads to an associated annual global increase in premature mortalities from respiratory disease in persons 30 years and older of 6,300 (95\% CI: 1,600-10,400) deaths (Fig. 3). The changes in mortality associated with $\mathrm{O}_{3}$ are approximately $5 \%$ of that from chronic exposure to $\mathrm{PM}_{2.5}$. Application of a LCT of $25 \mathrm{ppbv}$ to account for background $\mathrm{O}_{3}$ concentrations affects our mortality results very little and hence hereafter we report results without applying a LCT. The regional change in premature mortalities associated with chronic $\mathrm{O}_{3}$ exposure is shown in Table $\mathrm{S} 3$ in the SI. The increase in premature mortality from respiratory disease due to chronic $\mathrm{O}_{3}$ exposure is driven mostly by changes over South Asia (1,400 deaths, $1.0 \%)$, North America (1,000 deaths, $2.2 \%)$ and East Asia (4,300 deaths, $1.5 \%)$.

3) Summary

In North America, Europe, South and East Asia, 21st century climate change induced changes in both $\mathrm{PM}_{2.5}$ and $\mathrm{O}_{3}$ surface concentrations are projected to increase premature
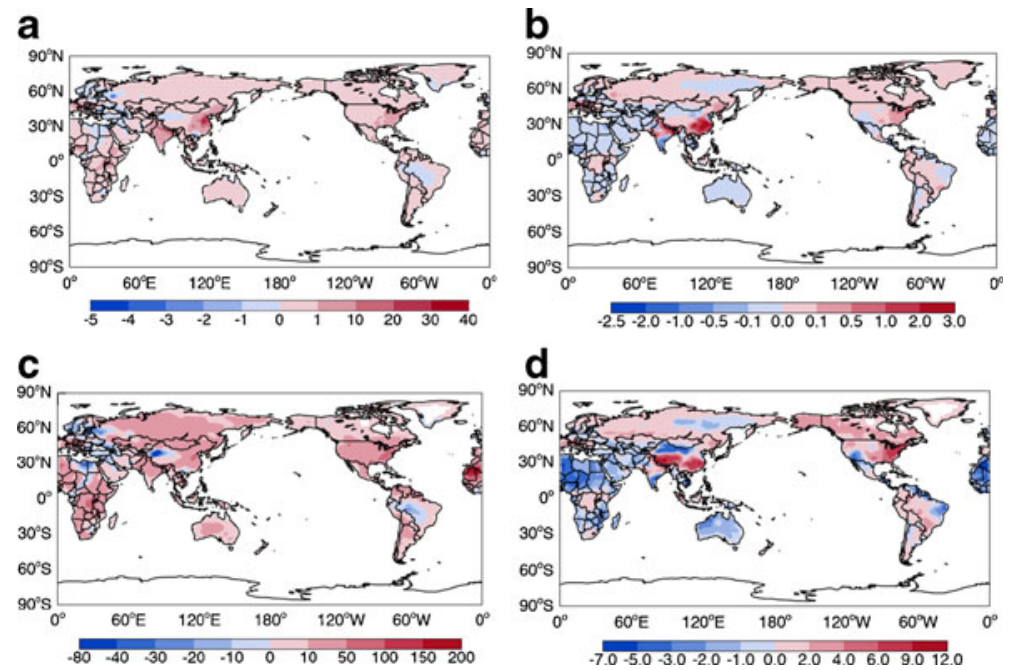

Fig. 3 Estimated change in premature mortalities associated with changes in surface $\mathrm{PM}_{2.5}$ (left column) and $\mathrm{O}_{3}$ (right column) resulting from 21 st century climate change (i.e., "future" minus "present" simulations). a, c shows changes due to $\mathrm{PM}_{2.5}$ and $\mathbf{b}$, d shows changes due to $\mathrm{O}_{3}$. (units: (a, b) additional annual premature mortalities per $1,000 \mathrm{~km}^{2},(\mathbf{c}, \mathbf{d})$ additional annual premature mortalities per million population) 
mortality under the scenario of a constant population, baseline mortality rate and emissions of short-lived air pollutants. Climate change generates an air quality "climate penalty" by increasing surface concentrations of air pollutants and associated human health risks. As a result, stronger emission controls will be needed in many regions to maintain current air quality and public health. In the Middle East, climate change tends to reduce surface concentrations of $\mathrm{PM}_{2.5}$ and $\mathrm{O}_{3}$ and thus could potentially contribute to a public health "climate benefit". However, uncertainties associated with this benefit are large. In addition, premature mortality resulting from higher temperatures, insufficient food supply and greater malarial risk will likely counteract this benefit (Husain and Chaudhary 2008).

\subsection{Climate change impact on YLL attributed to $\mathrm{PM}_{2.5}$ and $\mathrm{O}_{3}$ exposure}

Figure $4 \mathrm{a}$ and $\mathrm{b}$ show the baseline all-cause and respiratory disease YLL per death $\left(\mathrm{YLL}_{\mathrm{unit}}\right.$ death) for adults aged 30 and older, respectively, calculated using (H2). Figure $4 \mathrm{c}$ and e show

a

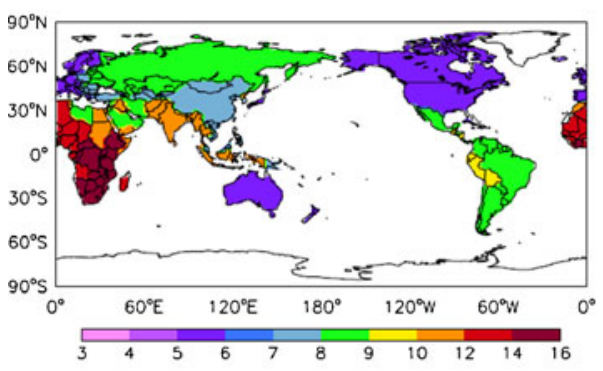

C

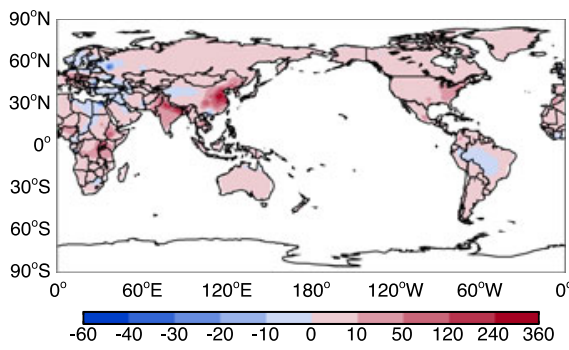

e

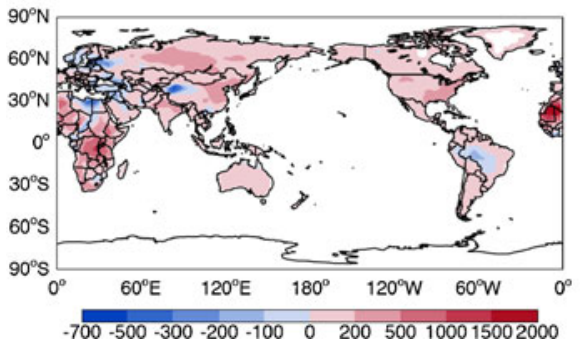

b

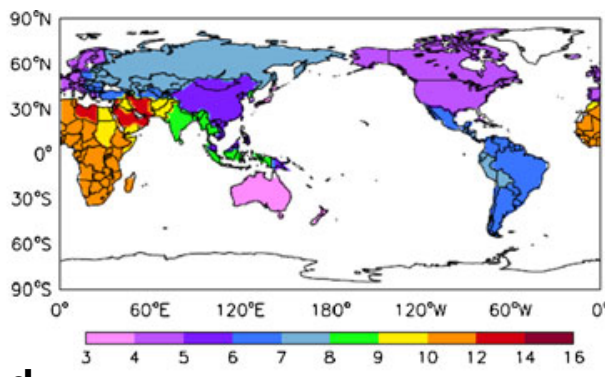

d

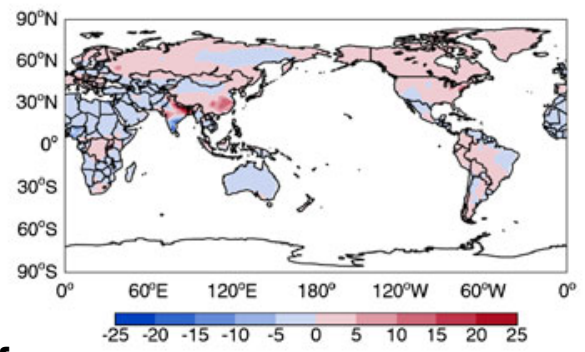

f

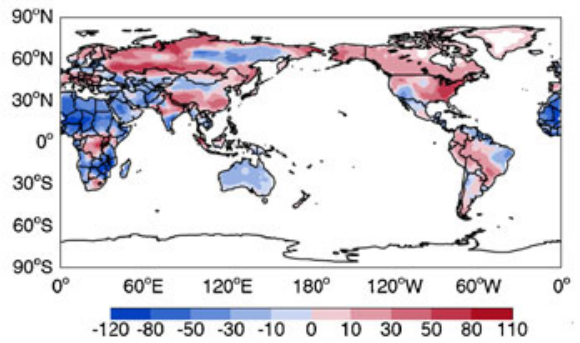

Fig. 4 Baseline YLL per death due to a all-cause and $\mathbf{b}$ respiratory disease mortality for adults aged 30 and older (WHO 2004) (unit: years/death). Changes in the estimated YLL due to changing PM $_{2.5}$ (left column) and $\mathrm{O}_{3}$ (right column) in a future climate (unit: $(\mathbf{c}, \mathbf{d})$ years per $1,000 \mathrm{~km}^{2} ;(\mathbf{e}, \mathbf{f})$ years per 1 million population) 
the estimated change in all-cause YLL for adults 30 and older due to 21 st century climate change induced changes in surface $\mathrm{PM}_{2.5}$ while Figure $4 \mathrm{~d}$ and $\mathrm{f}$ show the estimated change in YLL due to respiratory disease mortality under a future climate due to changes in $\mathrm{O}_{3}$ exposure (using (H3)).

Globally, the all-cause YLL from changes in $\mathrm{PM}_{2.5}$ is projected to increase by about 0.9 million years, a $4.1 \%$ increase relative to the end of the 20th century all-cause YLL (21 million) from $\mathrm{PM}_{2.5}$. The change in $\mathrm{PM}_{2.5}$-induced all-cause YLL over specific regions is shown in S4 in the SI. East Asia and South Asia have the most YLL due to the largest increase in premature mortality. Due to the much higher baseline YLL per death in Africa than North America (about 15 vs. 5 YLL per death), Africa has more YLL due to climate change induced changes in $\mathrm{PM}_{2.5}$ than North America, despite North America having a larger relative increase in premature mortalities. YLL attributed to climate-induced changes in $\mathrm{O}_{3}$ exposure is about 38,000 years, a relative increase of $0.5 \%$, much smaller than that due to changes in $\mathrm{PM}_{2.5}$ exposure. The largest increases in YLL from $\mathrm{O}_{3}$ occur over East Asia, South Asia and North America while YLL due to $\mathrm{O}_{3}$ decrease over Africa and the Middle East (Table S4 in the SI).

The following is an example, per unit population, of the impact of $\mathrm{PM}_{2.5}$ and climate change induced changes in $\mathrm{PM}_{2.5}$ on YLL. For adults aged 30 and older, the YLL from allcause mortality per 1,000 population is about 123 years (WHO 2008b). The additional allcause YLL attributed to climate change induced increases in $\mathrm{PM}_{2.5}$ exposure in the 21st century per 1,000 population aged 30 and older is about 4.5 years. Due to climate change, YLL associated with $\mathrm{PM}_{2.5}$ exposure increases approximately $4 \%$ relative to YLL from total $\mathrm{PM}_{2.5}$ exposure at the end of the 20th century, resulting in approximately 2 months additional life lost per 1,000 persons globally.

\section{Discussion and conclusions}

We evaluate projected changes in premature mortality from the end of the 20th century to the end of the 21 st century resulting from climate change induced changes in surface $\mathrm{O}_{3}$ and $\mathrm{PM}_{2.5}$. Our study is based on climate change driven by the relatively conservative SRES A1B emission scenario. Using the global coupled CCM (AM3) we first find that climate change leads to increases in global population-weighted annual $\mathrm{PM}_{2.5}$ concentrations of $0.5 \mu \mathrm{g} / \mathrm{m}^{3}$ and global population-weighted $\mathrm{H}_{-} \mathrm{O}_{3}$ concentrations (defined in each grid box as the average of the 6 months with highest monthly average daily 1-h maximum $\mathrm{O}_{3}$ ) of 0.3 ppbv. We estimate associated premature mortality using concentration-response relationships obtained from the epidemiological literature (Jerrett et al. 2009; Krewski et al. 2009). Our results indicate that 21 st century climate change increases global all-cause premature mortalities associated with $\mathrm{PM}_{2.5}$ by approximately 100,000 deaths and respiratory disease mortality associated with $\mathrm{O}_{3}$ by 6,300 deaths annually.

Premature mortality resulting from exposure to local pollution in high-population urban centers is likely underestimated in our model due to its relatively coarse resolution, a similar limitation as reported by Liu et al. (2009) and Anenberg et al. (2010). To partly offset this effect and indicate the magnitude of the climate effect on mortalities associated with air pollution, we also report the relative change in premature mortality as the percent change between "present" and "future" simulations. 21st century climate change, under the A1B scenario, results in about a $4 \%$ increase in global all-cause mortality associated with $\mathrm{PM}_{2.5}$, and less than a $1 \%$ increase in respiratory disease mortality associated with $\mathrm{O}_{3}$. 
Assuming population, baseline mortality rates and reactive air pollution emissions do not change over the 21 st century, our sensitivity study indicates that climate change effects on air quality will increase premature mortality and YLL, suggesting the existence of an air pollution mediated "climate penalty" for health. Other climate-driven factors, not included in our simulations, may exacerbate this penalty. For example, biogenic hydrocarbon emissions increase with temperature and hence will likely increase with climate warming. As they are precursors of $\mathrm{O}_{3}$ and organic aerosols, their increase will likely enhance $\mathrm{O}_{3}$ and $\mathrm{PM}_{2.5}$ concentrations, particularly in high $\mathrm{NO}_{\mathrm{x}}$ regions. In addition, we do not consider the impact on tropospheric chemistry of a likely $\mathrm{CH}_{4}$ concentration increase of about $200 \mathrm{ppb}$ during the 21st century. Based on previous literature (Fang et al. 2013b; West et al. 2006b; Fiore et al. 2008; Anenberg et al. 2012), this increase in $\mathrm{CH}_{4}$ will likely raise background $\mathrm{O}_{3}$ by about $1 \mathrm{ppb}$. The effect of population growth is also not included in our sensitivity study. If population grow, as indicated in the A1B or A2 scenarios, during the 21 st century is considered, premature mortality associated with the climate change effect on $\mathrm{PM}_{2.5}$ will increase $4.4 \%$ (A1B) or $11 \%$ (A2) during the 21 st century (details shown in the SI).

Significant uncertainties are associated with our sensitivity study. We assume that the relative risks derived from the U.S. ACS epidemiological study (Jerrett et al. 2009; Krewski et al. 2009) are applicable globally, as supported by similar relative risks established in U.S. based time-series studies and in various studies in Europe (Levy et al. 2005; Anderson et al. 2004) and Asia (HEI 2010). However, lifestyles, age distributions, health status, and medical resources vary around the world possibly resulting in varied health responses to the same change in pollution level. Nevertheless, this is unlikely to change the sign of the results associated with this sensitivity study.

Another source of uncertainty is the simulated $\mathrm{O}_{3}$ and $\mathrm{PM}_{2.5}$ concentration changes driven by climate change. As an initial effort, we reviewed recent literature examining climate change effects on these two species. As summarized by Jacob and Winner (2009), there are still large uncertainties regarding model projections of future air quality, especially for $\mathrm{PM}_{2.5}$. However, most studies cited in this review and other more recent papers (Kloster et al. 2010; Fang et al. 2011) show an increase in $\mathrm{PM}_{2.5}$ over populated areas due to climate change (See Table S5 in the SI). There is one study by Tagaris et al. (2007) that shows a $10 \%$ decrease in annual mean $\mathrm{PM}_{2.5}$ over the United States, however, their companion paper (Tagaris et al. 2009) estimates increased mortality in the United States from $\mathrm{PM}_{2.5}$ exposure due to the coincidence of dense population and increases in $\mathrm{PM}_{2.5}$. Therefore, these previous studies generally support our conclusion that climate change imposes a penalty to air quality and associated human mortality risks, especially over populated regions. We further examined the standard deviation for concentration and mortality changes by comparing individual year results in our 20-year simulation to assess uncertainties arising from internal model variability. Using $\mathrm{PM}_{2.5}$ as an example, we find global mortality associated with $\mathrm{PM}_{2.5}$ is $4.1 \pm 1.5$ (as mean \pm standard deviation) \%, indicating that the increase in global mortality is fairly robust to internal model variability. However, some regions (such as the Middle East and Rest of Asia) have a standard deviation greater than the mean, indicating changes that are not significant from internal model variability.

In addition to these initial efforts, a systematic quantification of uncertainties associated with climate models and specific scenarios requires ensemble model studies, in which a variety of chemistry-climate models run the same sensitivity experiments that are then applied to examine the corresponding health effects associated with air pollution. Such ensemble model studies have been applied in Anenberg et al. (2009) to examine the health risks associated with inter-continental air pollution transport. Currently, there are on-going inter-model comparison projects (such as the Atmospheric Chemistry and Climate Model 
Intercomparison Project (ACCMIP 2012)) which will provide data for improved estimates of uncertainties.

Our study shows climate change exacerbates air pollution and increases associated health risks globally, especially over polluted regions. This result is consistent with conclusions drawn from studies focused on the United States (Bell et al. 2007; Jacobson 2008; Tagaris et al. 2009). Our study suggests that in the future to improve air quality and protect human health, environmental policies that reduce emissions of greenhouse gases and warming aerosols, as well as traditional air pollutants, will be beneficial. Reducing emissions of black carbon and methane would be particularly effective as mitigation of these pollutants can slow the rate of climate change while reducing concentrations of $\mathrm{PM}_{2.5}$ and $\mathrm{O}_{3}$ and their associated health risks (Shindell et al. 2012; Anenberg et al. 2012; Bond et al. 2013).

Open Access This article is distributed under the terms of the Creative Commons Attribution License which permits any use, distribution, and reproduction in any medium, provided the original author(s) and the source are credited.

\section{References}

ACCMIP (2012) The Atmospheric Chemistry and Climate Model Intercomparison Project (ACCMIP). Atmospheric Chemistry and Physics Discussion 12(8)

Anderson HR, Atkinson RW, Peacock JL, Marston L, Konstantinou K (2004) Meta-analysis of time-series studies and panel studies of Particulate Matter $(\mathrm{PM})$ and Ozone $\left(\mathrm{O}_{3}\right)$. World Health Institute, Copenhangen

Anenberg SC, West JJ, Fiore AM, Jaffe DA, Prather MJ, Bergmann D, Cuvelier K, Dentener FJ, Duncan BN, Gauss M, Hess P, Jonson JE, Lupu A, MacKenzie IA, Marmer E, Park RJ, Sanderson MG, Schultz M, Shindell DT, Szopa S, Vivanco MG, Wild O, Zeng G (2009) Intercontinental impacts of ozone pollution on human mortality. Environ Sci Technol 43(17):6482-6487. doi:10.1021/es900518z

Anenberg SC, Horowitz LW, Tong DQ, West JJ (2010) An estimate of the global burden of anthropogenic ozone and fine particulate matter on premature human mortality using atmospheric modeling. Environ Health Perspect 118(9):1189-1195. doi:10.1289/ehp.0901220

Anenberg SC, Schwartz J, Shindell D, Amann M, Faluvegi G, Klimont Z, Janssens-Maenhout G, Pozzoli L, Van Dingenen R, Vignati E, Emberson L, Muller NZ, West JJ, Williams M, Demkine V, Hicks WK, Kuylenstierna J, Raes F, Ramanathan V (2012) Global air quality and health co-benefits of mitigating near-term climate change through methane and black carbon emission controls. Environ Health Perspect

Bell ML, McDermott A, Zeger SL, Samet JM, Dominici F (2004) Ozone and short-term mortality in 95 US urban communities, 1987-2000. JAMA 292(19):2372-2378. doi:10.1001/jama.292.19.2372

Bell ML, Peng RD, Dominici F (2006) The exposure-response curve for ozone and risk of mortality and the adequacy of current ozone regulations. Environ Heal Perspect 114(4):532-536

Bell ML, Goldberg R, Hogrefe C, Kinney P, Knowlton K, Lynn B, Rosenthal J, Rosenzweig C, Patz J (2007) Climate change, ambient ozone, and health in 50 US cities. Clim Chang 82(1-2):61-76. doi:10.1007/ s10584-006-9166-7

Bond TC, Doherty SJ, Fahey DW, Forster PM, Berntsen T, DeAngelo BJ, Flanner MG, Ghan S, Kärcher B, Koch D, Kinne S, Kondo Y, Quinn PK, Sarofim MC, Schultz MG, Schulz M, Venkataraman C, Zhang H, Zhang S, Bellouin N, Guttikunda SK, Hopke PK, Jacobson MZ, Kaiser JW, Klimont Z, Lohmann U, Schwarz JP, Shindell D, Storelvmo T, Warren SG, Zender CS (2013) Bounding the role of black carbon in the climate system: a scientific assessment. J Geophys Res Atmos. doi:10.1002/jgrd.50171

CIESIN (2005) Gridded Population of the World (GPW), version 3. http://sedacciesincolumbiaedu/plue/gpw Croft B, Lohmann U, Martin RV, Stier P, Wurzler S, Feichter J, Hoose C, Heikkilä U, van Donkelaar A, Ferrachat $\mathrm{S}$ (2010) Influences of in-cloud aerosol scavenging parameterizations on aerosol concentrations and wet deposition in ECHAM5-HAM. Atmos Chem Phys 10(4):1511-1543. doi:10.5194/acp-10-1511-2010

Donner LJ, Wyman BL, Hemler RS, Horowitz LW, Ming Y, Zhao M, Golaz J-C, Ginoux P, Lin S-J, Schwarzkopf DM, Austin J, Alaka G, Cooke WF, Delworth TL, Freidenreich SM, Gordon CT, Griffies SM, Held IM, Hurlin WJ, Klein SA, Knutson TR, Langenhorst AR, Lee H-C, Lin Y, Magi BI, Malyshev SL, Milly PCD, Naik V, Nath MJ, Pincus R, Ploshay JJ, Ramaswamy V, Seman CJ, Shevliakova E, 
Sirutis JJ, Stern WF, Stouffer RJ, Wilson RJ, Winton M, Wittenberg AT, Zeng F (2011) The dynamical core, physical parameterizations, and basic simulation characteristics of the atmospheric component AM3 of the GFDL global coupled model CM3. J Clim 24(13):3484-3519. doi:10.1175/2011JCLI3955.1

Fang Y, Fiore AM, Horowitz LW, Gnanadesikan A, Held I, Chen G, Vecchi G, Levy H (2011) The impacts of changing transport and precipitation on pollutant distributions in a future climate. J Geophys Res 116(D18), D18303. doi:10.1029/2011jd015642

Fang Y, Fiore AM, Lamarque J-F, Horowitz LW, Lin M (2013a) Using synthetic tracers as a proxy for summertime PM2.5 air quality over the Northeastern United States in physical climate models. Geophys Res Lett. doi:10.1002/grl.50162

Fang Y, Naik V, Horowitz LW, Mauzerall DL (2013b) Air pollution and associated human mortality: the role of air pollutant emissions, climate change and methane concentration increases from the preindustrial period to present. Atmos Chem Phys 13(3):1377-1394. doi:10.5194/acp-13-1377-2013

Fiore AM, West JJ, Horowitz LW, Naik V, Schwarzkopf MD (2008) Characterizing the tropospheric ozone response to methane emission controls and the benefits to climate and air quality. J Geophys Res 113(D8), D08307. doi:10.1029/2007jd009162

Fiore AM, Naik V, Spracklen D, Steiner A, Unger N, Prather M, Bergmann D, Cameron-Smith PJ, Cionni I, Collins WJ, Dalsøren S, Eyring V, Folberth GA, Ginoux P, Horowitz LW, Josse B, Lamarque J-F, Mackenzie IA, Nagashima T, O’Connor FM, Righi M, Rumbold S, Shindell DT, Skeie RB, Sudo K, Szopa S, Takemura T, Zeng G (2012) Global air quality and climate. Chem Soc Rev. doi:10.1039/c2cs35095e

GAMDT (2004) The new GFDL global atmosphere and land model AM2, ÄiLM2: evaluation with prescribed sst simulations. J Clim 17(24):4641-4673. doi:10.1175/jcli-3223.1

Ginoux P, Chin M, Tegen I, Prospero JM, Holben B, Dubovik O, Lin S-J (2001) Sources and distributions of dust aerosols simulated with the GOCART model. J Geophys Res 106(D17):20255-20273. doi:10.1029/ 2000jd000053

Hales S, de Wet N, Maindonald J, Woodward A (2002) Potential effect of population and climate changes on global distribution of dengue fever: an empirical model. Lancet 360(9336):830-834. doi:10.1016/S01406736(02)09964-6

HEI (2010) Public Health and Air Pollution in Asia (PAPA): coordinated studies of short-term exposure to air pollution and daily mortality in four cities. Health Effects Institute, Boston

Horowitz LW, Walters S, Mauzerall DL, Emmons LK, Rasch PJ, Granier C, Tie X, Lamarque J-F, Schultz MG, Tyndall GS, Orlando JJ, Brasseur GP (2003) A global simulation of tropospheric ozone and related tracers: Description and evaluation of MOZART, version 2. J Geophys Res 108(D24):4784. doi:10.1029/ 2002jd002853

Husain T, Chaudhary J (2008) Human health risk assessment due to global warming, a case study of the gulf countries. Int J Environ Res Public Health 5(4):204-212. doi:10.3390/ijerph5040204

Jacob DJ, Winner DA (2009) Effect of climate change on air quality. Atmos Environ 43(1):51-63. doi:10.1016/j.atmosenv.2008.09.051

Jacobson MZ (2008) On the causal link between carbon dioxide and air pollution mortality. Geophys Res Lett 35(3), L03809. doi:10.1029/2007gl031101

Jerrett M, Burnett RT, Pope AC, Ito K, Thurston G, Krewski D, Shi Y, Calle E, Thun M (2009) Long-term ozone exposure and mortality. N Engl J Med 360(11):1085-1095. doi:10.1056/NEJMoa0803894

Kloster S, Dentener F, Feichter J, Raes F, Lohmann U, Roeckner E, Fischer-Bruns I (2010) A GCM study of future climate response to aerosol pollution reductions. Clim Dyn 34(7):1177-1194. doi:10.1007/s00382009-0573-0

Krewski D, Jerrett M, Burnett RT, Ma R, Hughes E, Shi Y, Turner MC, Pope CA, Thurston G, Calle EE, Thun MJ, Beckerman B, DeLuca P, Finkelstein N, Ito K, Moore DK, Newbold KB, Ramsay T, Ross Z, Shin H, Tempalski B (2009) Extended follow-up and spatial analysis of the American Cancer Society study linking particulate air pollution and mortality. Research report. Health Effects Institute, Cambridge

Levy JI, Chemerynski SM, Sarnat JA (2005) Ozone exposure and mortality: "an empiric Bayes metaregression analysis". Epidemiology 16(4):458-468. doi:10.1097/01.ede.0000165820.08301.b3

Li J, Wang Z, Akimoto H, Gao C, Pochanart P, Wang X (2007) Modeling study of ozone seasonal cycle in lower troposphere over East Asia. J Geophys Res 112(D22):D22S25. doi:10.1029/2006jd008209

Liao H, Chen W-T, Seinfeld JH (2006) Role of climate change in global predictions of future tropospheric ozone and aerosols. J Geophys Res 111, D12304. doi:10.1029/2005jd006852

Liu J, Mauzerall DL, Horowitz LW (2009) Evaluating inter-continental transport of fine aerosols: (2) global health impact. Atmos Environ 43(28):4339-4347. doi:10.1016/j.atmosenv.2009.05.032

Mauzerall DL, Narita D, Akimoto H, Horowitz L, Walters S, Hauglustaine DA, Brasseur G (2000) Seasonal characteristics of tropospheric ozone production and mixing ratios over East Asia: a global threedimensional chemical transport model analysis. J Geophys Res 105(D14):17895-17910. doi:10.1029/ 2000jd900087 
Meehl GA, Stocker TF, Collins WD, Friedlingstein AT, Gaye AT, Gregory JM, Kitoh A, Knutti R, Murphy JM, Noda A, Raper SCB, Watterson IG, Weaver AJ, Zhao Z (2007) Global climate projections. In: Soloman S, Qin D, Manning M et al. (eds) Climate change 2007: the physical science basis. contribution of working group I to the fourth assessment report of the intergovernmental panel on climate change. Cambridge University Press pp 747-845

Mickley LJ, Jacob DJ, Field BD, Rind D (2004) Effects of future climate change on regional air pollution episodes in the United States. Geophys Res Lett 31(L24103). doi:10.1029/2004g1021216

Ming Y, Ramaswamy V, Donner LJ, Phillips VTJ (2006) A new parameterization of cloud droplet activation applicable to general circulation models. J Atmos Sci 63(4):1348-1356. doi:10.1175/jas3686.1

Murazaki K, Hess P (2006) How does climate change contribute to surface ozone change over the United States? J Geophys Res 111(D05301):D05301. doi:10.1029/2005jd005873

Parry ML, Canziani OF, Palutikof JP, van der Linden PJ, Hanson CE (2007) Contribution of working group II to the fourth assessment report of the intergovernmental panel on climate change, 2007. Cambridge University Press, Cambridge, United Kingdom and New York, NY, USA

Pope CA, Dockery DW (2006) Health effects of fine particulate air pollution: lines that connect. J Air Waste Manag Assoc 56(6):709-742

Pope CA, Burnett RT, Thun MJ, Calle EE, Krewski D, Ito K, Thurston GD (2002) Lung cancer, cardiopulmonary mortality, and long-term exposure to fine particulate air pollution. J Am Med Assoc 287(9):11321141. doi:10.1001/jama.287.9.1132

Portier CJ, Thigpen TK, Carter S, Dilworth C, Grambsch A, Gohlke J, Hess J, Howard S, Luber G, Lutz J, Maslak T, Prudent N, Radtke M, Rosenthal J, Rowles T, Sandifer P, Scheraga J, Schramm P, Strickman D, Trtanj J, Whung P-Y (2010) A human health perspective on climate change: a report outlining the research needs on the human health effects of climate change. Environmental Health Perspectives/ National Institute of Environmental Health Sciences, Research Triangle Park, NC. doi:10.1289/ ehp. 1002272

Racherla PN, Adams PJ (2006) Sensitivity of global tropospheric ozone and fine particulate matter concentrations to climate change. J Geophys Res 111(D24103). doi:10.1029/2005jd006939

Reichler T, Kim J (2008) How well do coupled models simulate today's climate? Bull Am Meteorol Soc 89(3):303-311. doi:10.1175/BAMS-89-3-303

Rosenzweig C, Iglesias A, Yang XB, Epstein PR, Chivian E (2001) Climate change and extreme weather events; Implications for food production, plant diseases, and pests. Glob Chang Hum Health 2(2):90-104. doi:10.1023/a:1015086831467

Schwartz J, Coull B, Laden F, Ryan L (2007) The effect of dose and timing of dose on the association between airborne particles and survival. Environ Health Perspect 116(1):64-69. doi:10.1289/ehp.9955

Shindell D, Kuylenstierna JCI, Vignati E, van Dingenen R, Amann M, Klimont Z, Anenberg SC, Muller N, Janssens-Maenhout G, Raes F, Schwartz J, Faluvegi G, Pozzoli L, Kupiainen K, Höglund-Isaksson L, Emberson L, Streets D, Ramanathan V, Hicks K, NTK O, Milly G, Williams M, Demkine V, Fowler D (2012) Simultaneously mitigating near-term climate change and improving human health and food security. Science 335(6065):183-189. doi:10.1126/science.1210026

Tagaris E, Manomaiphiboon K, Liao K-J, Leung LR, Woo J-H, He S, Amar P, Russell AG (2007) Impacts of global climate change and emissions on regional ozone and fine particulate matter concentrations over the United States. J Geophys Res 112:D14312. doi:10.1029/2006JD008262

Tagaris E, Liao K-J, DeLucia AJ, Deck L, Amar P, Russell AG (2009) Potential impact of climate change on air pollution-related human health effects. Environ Sci Technol 43(13):4979-4988. doi:10.1021/es803650w

Tanser FC, Sharp B, le Sueur D (2003) Potential effect of climate change on malaria transmission in Africa. Lancet 362(9398):1792-1798. doi:10.1016/s0140-6736(03)14898-2

Weaver CP, Liang XZ, Zhu J, Adams PJ, Amar P, Avise J, Caughey M, Chen J, Cohen RC, Cooter E, Dawson JP, Gilliam R, Gilliland A, Goldstein AH, Grambsch A, Grano D, Guenther A, Gustafson WI, Harley RA, He S, Hemming B, Hogrefe C, Huang H-C, Hunt SW, Jacob D, Kinney PL, Kunkel K, Lamarque JF, Lamb BK, Larkin N, Leung L-YR, Liao K-J, Lin J, Lynn BH, Manomaiphiboon K, Mass CS, KcKenzie D, Mickley LJ, O’Neil S, Nolte C, Pandis SN, Racherla PN, Rosenzweig C, Russell AG, Salathe E, Steiner AL, Tagaris E, Tao Z, Tonse S, Wiedinmyer C, Williams A, Winner DA, Woo J-H, Wu S, Wuebbles DJ (2009) A preliminary synthesis of modeled climate change impacts on U.S. regional ozone concentrations. Bull Am Meteorol Soc 90(12):1843-1863. doi:10.1175/2009BAMS2568.1

West JJ, Fiore AM, Horowitz LW, Mauzerall DL (2006a) Global health benefits of mitigating ozone pollution with methane emission controls. Proc Natl Acad Sci U S A 103(11):3988-3993. doi:10.1073/ pnas.0600201103

West JJ, Fiore AM, Horowitz LW, Mauzerall DL (2006b) Global health benefits of mitigating ozone pollution with methane emission controls. Proc Natl Acad Sci 103(11):6. doi:10.1073/pnas.0600201103 
WHO (2004) Global Burden of Disease (GBD) 2000: version 3 estimates. http://wwwwhoint/healthinfo/ global_burden_disease/estimates_regional_2000_v3/en/indexhtml

WHO (2008a) The global burden of disease: $200 \overline{4}$ update. http://wwwwhoint/healthinfo/global burden disease/2004 report update/en/indexhtml

WHO (2008b) WHO mortality database: tables http://wwwwhoint/healthinfo/morttables/en/

Wu S, Mickley LJ, Leibensperger EM, Jacob DJ, Rind D, Streets DG (2008) Effects of 2000-2050 global change on ozone air quality in the United States. J Geophys Res 113(D06302). doi:10.1029/2007jd008917 